\title{
Tracing Paleoclimatic Signatures in Fossil Woods and Sub-fossil Logs of Kerala, Southwestern India
}

\author{
K.P.N. Kumaran ${ }^{1}$ and K.M. NaIR ${ }^{2}$ \\ ${ }^{1}$ Palaeobiology Group, Agharkar Research Institute, G.G. Agarkar Road, Pune, India; kpnkumaran@hotmail.com \\ ²akkom Moulavi Foundation, Thekkummoodu Jn, Thiruvananthapuram, Kerala, India; vmft@asianetindia.com
}

Fossil woods and sub-fossil logs, the hard and compact parts of plant remains, are an important source of information on environmental changes of the geological and recent past, as they show detailed cellular structure that can be compared with a modern analogue. Unlike those of older geological periods, Quaternary woods are fossilized as 'fusains', a charcoal-like material, in the lignites and peats or remain undecayed as sub-fossil. Provided they possess annual growth rings, these fossils form a valuable source of climatic data where there is a lack of contemporaneous meteorological records. As growth ring formation is primarily related to climatic conditions, a few of these woods may turn out to be potential species for assessing the pattern of climatic changes in the last few thousand years. Such an application is already gaining importance in paleoclimatic research (Bhattacharyya et al., 1992; Creber and Francis, 1999).

It is estimated that about $25 \%$ of the tropical trees in India are known to produce growth rings (Chowdhury, 1964) but climatecontrolled growth-ring formation occurs in only a few species. Most of these broad-leaved tropical trees have persisted since the Miocene along the west coast of India (Srivastava and Awasthi, 1996), and, as such, there is great potential for their use in dendroclimatic analysis. Teak (Tectona grandis), Cedrela (C. angustifolia) and Toon (Toona ciliata) are some of the species with distinct growth rings that have already been exploited for tropical dendroclimatology (Bhatttacharyya and Yadav, 1989; Tomazello et al., 2001). However, new techniques involving stable carbon and oxygen isotopes as indicators for processes underlying tree growth and climate proxies

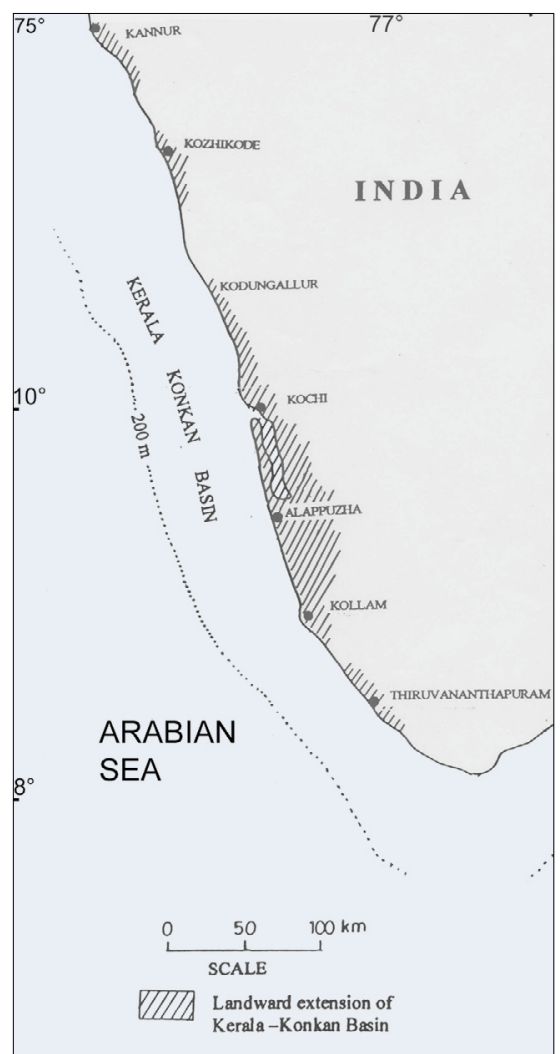

Fig. 1: Landward extension of Kerala-Konkan Basin. The shaded part represents the location of the South Kerala sedimentary basin study area between Kollam and Kodungallur.

may help when studying tropical trees with indistinct growth rings (Helle and Panferov, 2004; Verheyden et al., 2004). By using such techniques, it may be possible to track climatic signals back to preinstrumental times. Tree trunks embedded in carbonaceous and silty clays at different stratigraphic levels from several locations along the Kollam-Kodungalloor stretch of the South Kerala sedimentary basin (Fig. 1) are described here, and their importance as potential archives of Late Quaternary environment addressed.

There have been a few reports of fossil woods from the Late Quaternary deposits of this stretch of Kerala (Agarwal et al.,1970; Nair et al., in press, Guleria et al., 2004). Rarely, however, are these reports accompanied by any description of the geological settings and tapho- nomy associated with the fossils. Neither the spatial and temporal distribution, nor the dendroclimatic aspects of these woods have been described so far, despite the fact that the woods have been excavated and used by local inhabitants for many decades. Moreover, except for a few radiocarbon dates, no other details are available, though the woods form potential archives of environmental changes and paleoclimatic signatures.

Large and small trunks of trees, often with their bark and parts of their roots and branches intact, are very common in the seasonal and perennial wetlands. In some cases, the woods are partly carbonized, especially the Late Pleistocene sequences. Holocene logs are generally found with bark and their hard woods intact (Fig. 2a, b). Although these fossil woods are yet to be identified based on anatomical characteristics, data (vernacular/ local names) provided by the local inhabitants reveal that at least 13 species of tropical wet evergreen and semi-evergreen forests occur in this region (Table 1). Some of these species have already been reported from the Neogene sediments (Miocene-Pliocene) belonging to the Warkalli Formation, and a few of them are still grown in sacred groves, relicts of the pristine forest that thrived until the Late Pleistocene-Early Holocene in the lowlands of Kerala (Nair et al., in press).

The accumulation of fossil woods and sub-fossils of large forest trees in huge quantity in the South Kerala coastal plains has considerable significance for inferring the ecology, depositional environment and geological events of the Late Quaternary. It is likely that extensive floods after the transgression might have caused massive destruction of the coastal forests, which in turn buried the 


\section{Science Highlights}

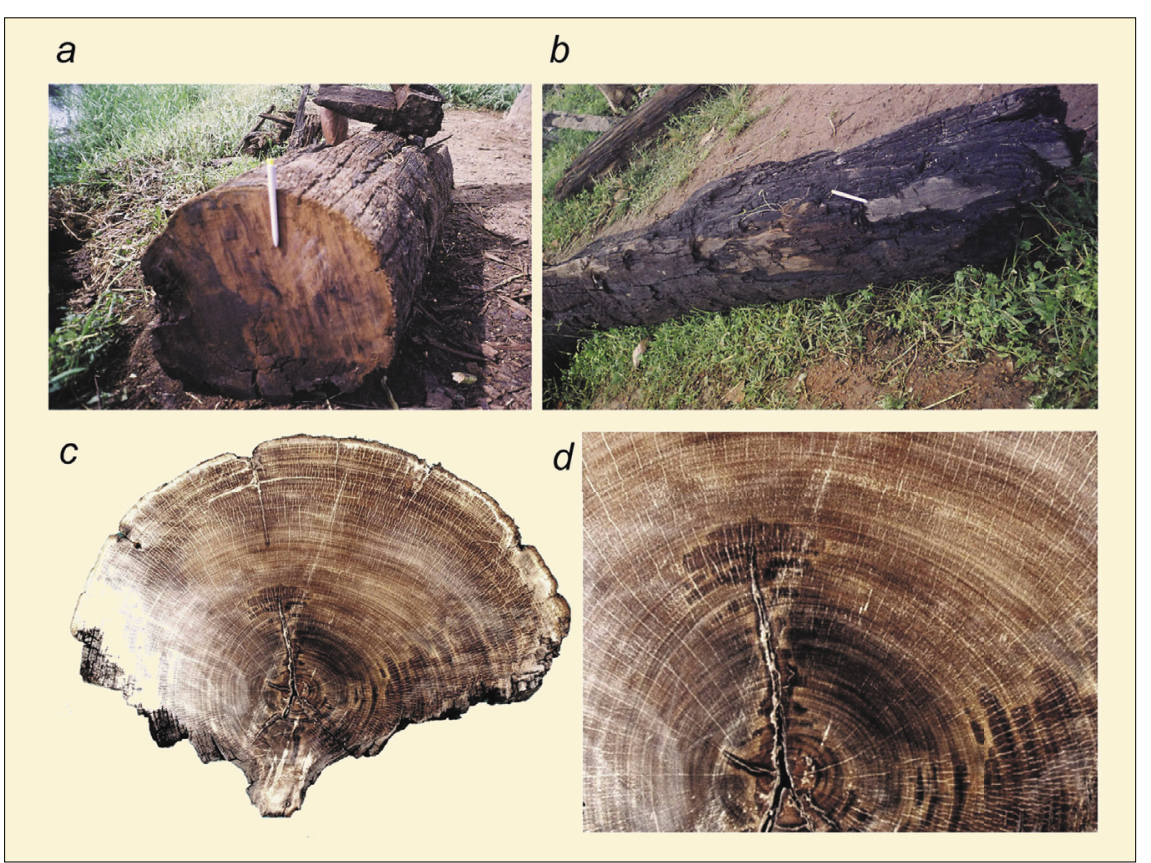

Fig. 2: Fossil wood and subfossil log of Kerala coast: a) Subfossil log excavated from the backwaters of Pathiyoor; Early Holocene. b) Partially carbonized fossil wood; Early Holocene. c) Cross section of specimen "a" showing growth-ring pattern. d) Sector enlarged view of specimen " $c$ " showing closer view of growth rings.

huge trunks of trees. Evidence for such large-scale floods and scouring in the Early Holocene has been presented recently for monsoon Asia (Kale et al., 2004). There fossils are believed to have accumulated in situ, as many of them possess intact roots and branches and some of them have bark, providing evidence of quick burial. This indicates that these fossils did not drift too far from their place of origin, and hence are of considerable significance in determining the provenance of the vegetation. A profuse growth of wet evergreen and semi-evergreen vegetation comprising many woody species, viz., Dipterocarpus, Hopea, Shorea, Diospyros, Canarium, Artocarpus, Mangifera, Pterocarpus, Toona, Leea and Cullenia (fossil pollen only) might have been aided by the high Asian Summer Monsoon reported to have been approx. three times greater than the present rate of rainfall.

The area of investigation presently receives annual rainfall ranging from 200 to $>500 \mathrm{~cm}$ of which $\sim 70 \%$ is from the SW-Monsoon, otherwise known as the Asian Summer Monsoon. Our analyses of the palynodebris and sediment characteristics suggest that there were two periods of abnormally high rainfall, one before the Last Glacial Maximum (LGM) and another during the Early Holocene.
Many of the landforms in the coastal plains and several of the landforms in the hinterland have been shown to contain a partialto-complete record of the period from the Late Pleistocene to the Holocene. In addition, there are indications that some of these terrains were sub-aerially exposed lands that were thickly forested. As a result of abnormally high rainfall, coupled with tectonics and the antecedent landform characteristics, the trees that grew there were possibly uprooted and buried right there. This would be unique to this area, and therefore calls for detailed and systematic investigation with regard to sub-fossil wood and vegetational history.

As the fossil logs are found in abundance and are incorporated (coalified in varying degrees) into peat or lignite, the cellular details ought to have been preserved in them. The various processes involved in fossilization may

Table 1: List of fossil woods and subfossil logs excavated from the wetlands of Kerala, based on data obtained from the local inhabitants and their potential for dendroclimatological study. * Fossils known from the Neogene Kerala coast sequence.

\begin{tabular}{|c|c|c|c|c|}
\hline $\begin{array}{l}\text { Sr. } \\
\text { No. }\end{array}$ & $\begin{array}{l}\text { Vernacular } \\
\text { name } \\
\text { (Malayalam) }\end{array}$ & Botanical name & Family & $\begin{array}{l}\text { Anatomical } \\
\text { features }\end{array}$ \\
\hline 1. & Anjeli / Aini & $\begin{array}{l}{ }^{*} \text { Artocarpus } \\
\text { hirsutus Lamk. }\end{array}$ & Moraceae & $\begin{array}{l}\text { Growth rings } \\
\text { indistinct }\end{array}$ \\
\hline 2. & Plavu & $\begin{array}{l}{ }^{*} \text { Artocarpus } \\
\text { heterophyllous } \\
\text { Lamk }\end{array}$ & Moraceae & $\begin{array}{l}\text { Growth rings } \\
\text { indistinct }\end{array}$ \\
\hline 3. & $\begin{array}{l}\text { Kunthirikkam } \\
\text { (Pantham, } \\
\text { Thalli) }\end{array}$ & $\begin{array}{l}{ }^{*} \text { Canarium } \\
\text { strictum }\end{array}$ & Burseraceae & $\begin{array}{l}\text { Growth rings } \\
\text { indistinct to } \\
\text { distinct }\end{array}$ \\
\hline 4. & Eetty & $\begin{array}{l}\text { Dalbergia latifolia } \\
\text { Roxb. }\end{array}$ & $\begin{array}{l}\text { Fabaceae / } \\
\text { Papilionaceae }\end{array}$ & $\begin{array}{l}\text { Initial parenchyma } \\
\text { cells; Growth rings } \\
\text { fairly distinct }\end{array}$ \\
\hline 5. & Kambagam & $\begin{array}{l}{ }^{*} \text { Hopea parviflora } \\
\text { Bedd. }\end{array}$ & Dipterocarpaceae & $\begin{array}{l}\text { Growth rings } \\
\text { indistinct }\end{array}$ \\
\hline 6. & Elanjhi & $\begin{array}{l}\text { Mimusops elangi } \\
\text { L. }\end{array}$ & Sapotaceae & $\begin{array}{l}\text { Growth rings } \\
\text { indistinct }\end{array}$ \\
\hline 7. & Vengha & $\begin{array}{l}\text { Pterocarpus } \\
\text { marsupium } \\
\text { Roxb. }\end{array}$ & Fabaceae & $\begin{array}{l}\text { Growth rings } \\
\text { distinct to } \\
\text { indistinct }\end{array}$ \\
\hline 8. & Odal & $\begin{array}{l}\text { Sarcostigma } \\
\text { grandis Wight \& } \\
\text { Arn. }\end{array}$ & Icacinaceae & - \\
\hline 9. & Puli & $\begin{array}{l}\text { Tamrindus indica } \\
\text { L. }\end{array}$ & Caesalpiniaceae & $\begin{array}{l}\text { Growth ring } \\
\text { distinct to } \\
\text { indistinct }\end{array}$ \\
\hline 10. & Thekku & $\begin{array}{l}\text { Tectona grandis } \\
\text { L.f. }\end{array}$ & Verbenaceae & $\begin{array}{l}\text { Distinct growth } \\
\text { rings }\end{array}$ \\
\hline 11. & Pillamaruthu & $\begin{array}{l}{ }^{*} \text { Terminalia } \\
\text { paniculata Roth }\end{array}$ & Combretaceae & $\begin{array}{l}\text { Growth rings } \\
\text { indistinct }\end{array}$ \\
\hline 12. & Agil & $\begin{array}{l}\text { Toona ciliata } \\
\text { Roem. }\end{array}$ & Meliaceae & $\begin{array}{l}\text { Growth rings } \\
\text { distinct }\end{array}$ \\
\hline 13. & Mavu & Mangifera indica & Anacardiaceae & $\begin{array}{l}\text { Growth rings } \\
\text { indistinct }\end{array}$ \\
\hline
\end{tabular}


preserve the anatomical details of the wood so well that growthring studies may be carried out on them exactly as if they were modern wood. Although conifers in temperate and sub-alpine zones have been exploited for climatic reconstruction, tropical and subtropical trees, with the exception ofTeak (Tectona grandis), have been seldom tested. This is due to a lack of information on datable tree rings from the Indian subcontinent. Nevertheless, transverse sections of some of the fossil logs look similar to growth rings, although they are yet to be evaluated microscopically (Fig. 2c, d).

Further excavation and meticulous searching of the fossil woods and sub-fossil logs in the wetlands of Kerala may lead to the identification of additional potential species for dendroclimatic study. Although a few taxa have demonstrated the potential for climatic reconstruction of the historical period, no attempt has been made yet to examine the Holocene or recent past based on tree growth-ring studies. In fact, tree-ring studies of tropical forest species have not often been undertaken, though such studies would be of great significance in terms of investigating global climatic change. There is good scope for paleo-dendroclimatological study in India and what has been discovered so far appears to be only the begining.

\section{ACKNOWLedgements}

The authors are grateful to KSCSTE,

Thiruvanantha-puram for granting project No.56/03/KSCSTE. KMN thanks the DST, New Delhi for providing project ESS/23/ VES/006/98 that enabled him to initiate the study of subsurface sediments of Kerala. The infrastructure facilities provided by the authorities of ARI, Pune and VMFT, Thiruvananthapuram are appreciated. The facilities extended by Dr Jayasri Banerji, Officiating Director, BSIP, Lucknow, and discussion with Drs Amalav Bhattacharyya and R.R. Yadav of the same institute are duly acknowledged.

\section{REFERENCES}

Agarwal, D.P., Gupta, S.K. and Kusumgar, S., 1970: Radiocarbon dates of Quaternary samples. Current Science, 39: 219-22

Bhattacharyya, A. and Yadav, R.R., 1989: Dendroclimatic research in India. Proc. India Nat. Sci. Acad., 55: 696-701.

Chowdhury, K.A., 1964: Growth rings in Tropical trees and taxonomy. Jour. Ind. Bot. Society, 43: 334-34.

Creber, G.T., and Francis, J.E., 1999: Fossil tree-ring analysis: palaeodendrology. In: Jones T.P. and Rowe N.P. (editors) - Fossil plants and spores: Modern techniques:245-250. Geological Society, London.

Kale, V.S., Gupta A. and Singhvi A.K., 2004: Late Pleistocene-Holocene palaeohydrology of monsoon Asia. J. Geol. Soc. India, 64: 403-417.

Nair, K.M., Padmalal, D., \& Kumaran, K.P.N., in press: Quaternary geology of South Kerala Sedimentary basin - An outline. J. Geol.Soc. India.

Verheyden, A., Helle, G., Schleser, G.H., Dehairs, F., Beeckman, H. and Koedam, N., 2004: Annual cyclicity in high-resolution stable carbon and oxygen isotope ratios in the wood of the mangrove trees of Rhizophora mucronata. Plant, Cell \& Environment

For full references please consult: www.pages-igbp.org/products/newsletters/ref2005_1.html

\section{An Upwelling Seesaw in the Atlantic Ocean: Model Results and Paleoceanographic Evidence}

\section{Prange and M. Schulz}

DFG Research Center Ocean Margins and Dept. of Geosciences, University of Bremen, Klagenfurter Strasse, 28334 Bremen, Germany; mprange@palmod.uni-bremen.de; mschulz@palmod.uni-bremen.de

\section{Coastal Upwelling in the Atlantic Ocean}

Coastal upwelling regions are important areas of investigation for paleoclimate research because of their high-resolution sedimentary archives and their sensitivity to environmental changes. Understanding the interactions between coastal upwelling zones and climatic conditions is crucial for a proper interpretation of the sedimentary record. In the Atlantic Ocean, the two major coastal upwelling regions are located along the coasts of northwestern (Mauritanian upwelling zone) and southwestern Africa (BenguelaNamibia upwelling system). The strength of African coastal upwelling is a function of the alongshore winds, which in turn are closely tied to the trade-wind systems in both hemispheres. We analyzed the response of the major Atlan-

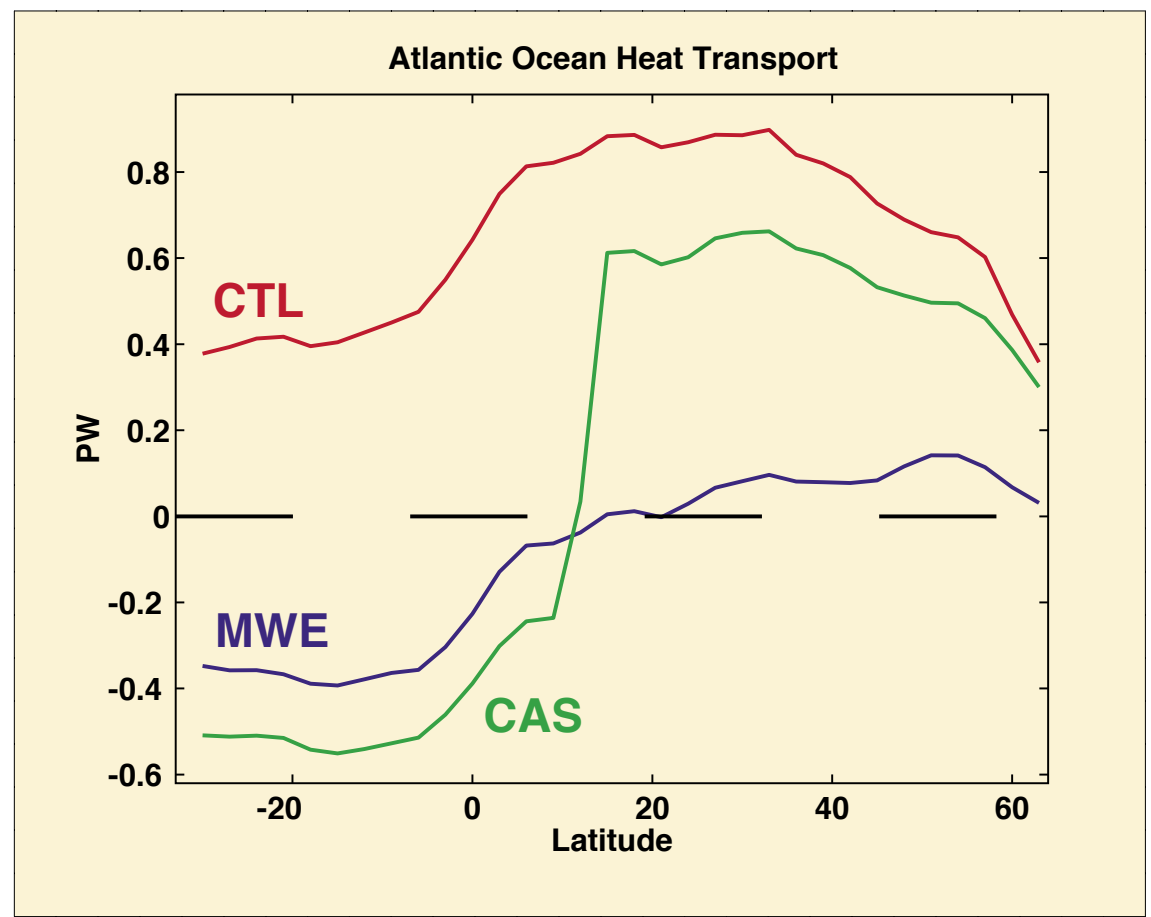

Fig. 1: Northward heat transport in the Atlantic Ocean for experiments CTL (control), MWE (meltwater event) and CAS (Central American Seaway). A reference temperature of $1.3^{\circ} \mathrm{C}$ has been used in the calculations. 